\title{
Age-Friendly Environments in ASEAN Plus Three: Case Studies from Japan, Malaysia, Myanmar, Vietnam, and Thailand
}

\author{
Sariyamon Tiraphat ${ }^{1, *}$, Doungjai Buntup ${ }^{1}$, Murallitharan Munisamy ${ }^{2}$, Thang Huu Nguyen ${ }^{3}$, \\ Motoyuki Yuasa ${ }^{4}$, Myo Nyein Aung ${ }^{4}\left[\right.$ and Aung Hpone Myint ${ }^{5}$ \\ 1 ASEAN Institute for Health Development, Mahidol University, Salaya, Phutthamonthon, \\ Nakhon Pathom 73170, Thailand; doungjai.bun@mahidol.ac.th \\ 2 National Cancer Society of Malaysia, Kuala Lumpur 50300, Malaysia; murallimd@gmail.com \\ 3 Institute for Preventive Medicine and Public Health, Hanoi Medical University, Hanoi 100000, Vietnam; \\ nguyenhuuthang@hmu.edu.vn \\ 4 Faculty of International Liberal Arts, Juntendo University, Tokyo 113-8421, Japan; \\ moyuasa@juntendo.ac.jp (M.Y.); dr.myonyeinaung@gmail.com (M.N.A.) \\ 5 Community Partners International (CPI), Bahan Township, Yangon 11201, Myanmar; \\ aunghponemyint88@gmail.com \\ * Correspondence: sariyamon.tir@mahidol.ac.th; Tel.: +66-2-441-9040-3 (ext. 18); Fax: +66-2-441-9044
}

Received: 21 May 2020; Accepted: 19 June 2020; Published: 23 June 2020

\begin{abstract}
Promoting age-friendly environment is one of the appropriate approaches to support quality of life toward ageing populations. However, the information regarding age-friendly environments in the Association of Southeast Asian Nations (ASEAN) Plus Three countries is still limited. This study aimed to survey the perceived age-friendly environments among ASEAN Plus Three older populations. The study employed cross-sectional quantitative research using multistage cluster sampling to select a sample of older adults in the capital cities of Japan, Malaysia, Myanmar, Vietnam and Thailand. The final sample was composed of 2171 older adults aged 55 years and over, including 140 Japanese, 510 Thai, 537 Malaysian, 487 Myanmarese, and 497 Vietnamese older adults. Data collection was conducted using a quantitative questionnaire with 20 items of perceived age-friendly environments with the rating scale based on the World Health Organization (WHO) standard. The score from the 20 items were analyzed and examined high-risk groups of "bad perception level" age-friendly environments using ordinal logistic regression. The research indicated the five highest inadequacies of age-friendly environments including: (1) participating in an emergency-response training session or drill which addressed the needs of older residents; (2) enrolling in any form of education or training, either formal or non-formal in any subject; (3) having opportunities for paid employment; (4) involvement in decision making about important political, economic and social issues in the community; and (5) having personal care or assistance needs met in the older adult's home setting by government/private care services. Information regarding the inadequacy of age-friendliness by region was evidenced to guide policy makers in providing the right interventions towards older adults' needs.
\end{abstract}

Keywords: age-friendly environments; emergency response; lifelong learning; political; economic; health; personal care; village health volunteer; ASEAN plus three; older populations

\section{Introduction}

Globally older populations are increasing more than other age groups with a faster rate in the developing countries [1]. Information from the United Nations indicated that in the year 1980 the older 
population was a majority ( $56 \%$ of persons aged 60 years or over) in developed countries. However, accordingly, in the future (2050) almost $80 \%$ of the older population aged 60 and over will be found in the less-developed countries [1]. Throughout the world, ageing populations have been the fastest growing in East Asia and Southeastern Asia where the percentage of the population aged 65 years or over almost doubled from 6\% in 1990 to $11 \%$ in 2019 [2].

Recognizing the growing trend of a worldwide ageing society, the World Health Organization (WHO) introduced the concept of an "age-friendly community" in 2005 and published a guide in 2007 [3]. There has been rapid growing interest in making communities more age-friendly and a large number of research studies have been undertaken on age-friendly environments based on the WHO guideline. For example, recent studies from Europe implemented the concept of age-friendly cities in The Netherlands and Poland. The studies illustrate the potential of making cities more appropriate to the needs of older people and to identify important challenges for active ageing in current and future generations. Some challenges involve the establishment of inclusive neighborhoods, such as making accessible neighborhoods with an adequate provision of services as well as the implementation of technology, such as using smart home-monitoring technologies for ageing societies [4-7]. In Canada, some researchers developed age-friendly indicators. The final list includes 39 indicators across eight domains that can support communities in their evaluation activities [8]. The domains are: outdoor space and buildings, transportation, housing, social participation, respect and social inclusion, civic participation and employment, communication, and community support and health services. Another study from Canada recommended the designing of age-friendliness for all states by promoting strategic engagements such as strengthening collaborative intersectoral relationships, implementing policy actions such as funding community projects, and development and exchange of knowledge such as the creation of a research community and policy network [9]. Several previous researchers in the United States also studied developing age-friendliness towards the older population such as improving the workforce in the field of aging $[10,11]$, strengthening social capital such as social connectivity associated with the older population's health benefits [12,13], and integrating research into a policy and planning agenda such as offering a policy to improve the physical and social environments for seniors [14-16]. In addition to Europe and America, many Australian researchers conducted studies regarding age-friendliness to promote quality of life towards Australian adults such as assessing the impact of political, physical, social, and research dimensions to implement 'ageing in place' in Australia [17-20].

In Asia, the Association of Southeast Asian Nations (ASEAN) Plus Three (APT) cooperation was founded to strengthen and deepen East Asia cooperation in various areas, particularly in economic, social, and political fields. Currently, APT includes the 10 members of the Association of Southeast Asian Nations (Brunei, Cambodia, Indonesia, Laos, Malaysia, Myanmar, the Philippines, Singapore, Thailand, and Vietnam) plus China, Japan, and South Korea. In 2016, to address and prepare for ageing societies, the APT presented a "statement on active ageing" in a purposeful manner to support the quality of life and well-being of the older persons in the regions [21]. To promote active ageing of older residents, a holistic approach of supportive and "age-friendly environments" for the older population included not only social and physical environments, but also economic security, and health care services as a national priority [21,22].

Despite the fact that ageing populations have been growing rapidly in the ASEAN Plus Three, a study to investigate age-friendly environments for older adults in the region is limited. Strengthening timely and effective policy cooperation towards active ageing, information and evidence regarding overview of age-friendly environments would be necessary. Therefore, this study aimed (1) to examine the availability of provided age-friendly environments; (2) to investigate whether the distribution of provided age-friendly environments differ by country; and (3) to identify high-risk groups of having inadequate age-friendly environments. Evidence of perceived age-friendly environment and risk groups will envision health and social authorities to create appropriate age-friendly environments based on the older populations' needs. 


\section{Methodology}

\subsection{Description of Survey and Study Population}

This research design was a cross-sectional household interview survey of perceived age-friendly environments towards the older populations in ASEAN Plus Three. The study used a multistage, stratified sampling procedure collecting data via face-to-face interviews during November 2018 to January 2019 in five metropolitan areas of Malaysia, Myanmar, Vietnam, Thailand, and Japan. We calculated the sample size using the number of older population aged 55 years and older in each metropolitan area above $(100,000$ cases/metropolis) $[2,23]$. Having been calculated by the Taro Yamane Formula method with $95 \%$ confidence, the sample size in each metropolitan area was about 400 cases. After adding a missing rate of $25 \%$, the expected final sample size for each metropolitan area was approximately 500 cases. However, we decided to have smaller numbers of data collection (about 150 cases) in Japan due to our resource limitations. For all countries, the first step was selection of a metropolitan area. In the second step, we randomly selected three or four districts from the metropolitan areas. In the third step, each subdistrict per district was selected. In the fourth step, every person 55 years of age and older living in the randomly selected households in the study area was eligible for the study. In the final fifth step, among all the eligible respondents in a household, one was randomly selected for interview. The response rate in each country was $100 \%$. The study population after excluding the observations with missing data was a total of 2171 persons aged 55 years and older. The observations remaining in the sample included 537 from Malaysia, 497 from Vietnam, 487 from Myanmar, 510 from Thailand, and 140 from Japan. This research project received ethical approval from the "Research Ethics Committee of the Faculty of Social Sciences and Humanities, Mahidol University" (Certificate of Approval No. 2018/218.1809). Informed consent was obtained from all study participants.

\subsection{Measures}

\subsubsection{Perceived Age-Friendly Environments}

All items of perceived age-friendly environments scale were obtained from the World Health Organization [3,24]. The final questionnaire of this study was adapted from the age-friendly environment questionnaire's Thai version, which has been validated with an older adult population in Thailand showing a good internal consistency validity $\alpha=0.89$ [25]. The perceived age-friendly environment scale is composed of 20 items for evaluating 8 domains that cities and communities can address to better adapt their structures and services to the needs of older people. The domains are the built environment, transport, housing, social participation, respect and social inclusion, civic participation and employment, communication, and community support and health services [3]. Each individual item of the age-friendly environments is scored from 0 to 4 on a response ordinal scale (not at all, a little, moderately, mostly, extremely), with higher scores indicating a higher perception of age-friendly environments. In this study, to examine whether distribution of provided age-friendly environments differ by country, we integrated and classified the perceived age-friendly environments from five levels into three levels as bad (not at all/a little), fair (moderately), and good (mostly/extremely). Internal consistency for the perceived Age-friendly environments in this study sample was $\alpha=0.87$, with $0.80,0.67,0.79,0.88$, and 0.84 for Malaysia, Vietnam, Myanmar, Thailand, and Japan respectively.

\subsubsection{Sociodemographic Variables}

In order to identify high-risk groups of perceived age-friendliness inadequacy, we put age levels as $1=55-64$ years, $2=65-74$ years, $3=75$ years and higher, and designated gender, and placed educational levels at $1=$ At least primary school, $2=$ High school, and $3=$ More than high school as the predictors. 


\subsection{Data Analysis}

Data were analyzed using the 2012 released IBM SPSS Statistics for Windows, Version 21.0, (Armonk, NY, USA). Descriptive analysis was used to describe the sample. In order to survey the availability of perceived age-friendly environment, the average score of each individual item of the response ordinal scale (0-4) for age-friendly environments was calculated with the average higher scores indicating more availability of age-friendly environments. In order to examine differences in the proportion of perceived age-friendly environment by country, we recoded the perception into 3 levels as bad (not at all/a little), fair (moderately), and good (mostly/extremely) and did the analysis using Pearson chi-squared test. Finally, to identify high-risk groups experiencing inadequate age-friendliness, ordinal logistic regression analysis was applied to investigate the predictors including age level, gender, educational level, and participant's country of higher perceived age-friendly environment. The level of significance for all analyses was set at $p<0.05$.

\section{Results}

\subsection{Sample Characteristics}

The total study sample included 2171 older persons (55 years or more). About three-fifths (61.6\%) of the sample were women. They had completed elementary school (42.1\%), high school (24.3\%), and more than high school (33.7\%). The older adults are more in the ages between 55-64 years (44.6\%), followed by $38.2 \%$ for the ages between $65-74$ years, and $17.2 \%$ for the older population at 75 years or higher. They live in Malaysia, Vietnam, Myanmar, Thailand, and Japan with $N=537,497,487,510$, and 140 respectively (see Table 1 ).

Table 1. Sample characteristics.

\begin{tabular}{|c|c|c|c|c|c|c|c|c|c|c|c|c|}
\hline \multirow{3}{*}{ Variables } & \multicolumn{12}{|c|}{ Country } \\
\hline & \multicolumn{2}{|c|}{$\begin{array}{l}\text { Malaysia } \\
(N=537)\end{array}$} & \multicolumn{2}{|c|}{$\begin{array}{c}\text { Vietnam } \\
(N=497)\end{array}$} & \multicolumn{2}{|c|}{$\begin{array}{l}\text { Myanmar } \\
(N=487)\end{array}$} & \multicolumn{2}{|c|}{$\begin{array}{l}\text { Thailand } \\
(N=510)\end{array}$} & \multicolumn{2}{|c|}{$\begin{array}{c}\text { Japan } \\
(N=140)\end{array}$} & \multicolumn{2}{|c|}{$\begin{array}{c}\text { Total } \\
(N=2171)\end{array}$} \\
\hline & $N$ & $\%$ & $n$ & $\%$ & $N$ & $\%$ & $n$ & $\%$ & $N$ & $\%$ & $n$ & $\%$ \\
\hline \multicolumn{13}{|l|}{ 1. Education } \\
\hline 1.1 At least Primary school & 19 & 3.5 & 165 & 33.2 & 415 & 85.2 & 313 & 61.4 & 1 & 0.7 & 913 & 42.1 \\
\hline 1.2 High school & 90 & 16.8 & 247 & 49.7 & 68 & 14.0 & 110 & 21.6 & 12 & 8.6 & 527 & 24.3 \\
\hline 1.3 More than high school & 428 & 79.7 & 85 & 17.1 & 4 & 0.8 & 87 & 17.1 & 127 & 90.7 & 731 & 33.7 \\
\hline \multicolumn{13}{|l|}{ 2. Gender } \\
\hline 2.1 Male & 233 & 43.4 & 212 & 42.7 & 164 & 33.7 & 146 & 28.6 & 78 & 55.7 & 833 & 38.4 \\
\hline 2.2 Female & 304 & 56.6 & 285 & 57.3 & 323 & 66.3 & 364 & 71.4 & 62 & 44.3 & 1338 & 61.6 \\
\hline \multicolumn{13}{|l|}{ 3. Age level } \\
\hline 3.1 55-64 years & 376 & 70.0 & 185 & 37.2 & 201 & 41.3 & 200 & 39.2 & 6 & 4.3 & 968 & 44.6 \\
\hline $3.265-74$ years & 144 & 26.8 & 218 & 43.9 & 191 & 39.2 & 194 & 38.0 & 83 & 59.3 & 830 & 38.2 \\
\hline 3.375 years and higher & 17 & 3.2 & 94 & 18.9 & 95 & 19.5 & 116 & 22.7 & 51 & 36.4 & 373 & 17.2 \\
\hline
\end{tabular}

\subsection{Availability of Perceived Age-Friendly Environments}

Availability of perceived age-friendly environments are analyzed from the scores for each one of the 20 items of an age-friendly environment. Average score of each individual item of the response ordinal scale (0-4) for age-friendly environments was calculated and compared with average higher scores indicating more availability of age-friendly environments.

Table 2 indicates average score of perceived age-friendly environments. We found that the five lowest average scores of perceived age-friendly environment in ASEAN Plus Three are as follows: (1) participating in an emergency response training session or drill in the past year which addressed the needs of older residents (mean score $=0.58$ ); (2) enrolling in any form of education or training, either formal or non-formal, in any subject in the past year(mean score $=1.04$ ); (3) having opportunities 
for paid employment (mean score $=1.06)$; $(4)$ involving in decision making about important political, economic and social issues in the community(mean score $=1.07$ ); and (5) having personal care or assistance needs met in a home setting, e.g., home care nursing/hospice care/non-governmental organization $(\mathrm{NGO}) /$ volunteers (mean score $=1.10$ ).

In contrast, the five highest average score of perceived age-friendly environments in ASEAN Plus Three are as follows: (1) feeling safe in the neighborhood (mean score $=2.61$ ); (2) feeling respected and socially included in the community (mean score $=2.18$ ); (3) local sources of information about your health concerns and service needs are available (mean score $=1.91)$; $(4)$ the neighborhood is suitable for walking, including for those who use wheelchairs and other mobility aids (mean score $=1.89$ ); and (5) house has been renovated, or can be renovated to fulfil needs in order to support the activities of daily living (mean score $=1.86$ ).

Table 2. Average score of perceived age-friendly environments calculated from the average of a five rating scale (0-4) with $0=$ not at all, $1=$ a little, $2=$ moderate, $3=$ mostly, $4=$ extremely.

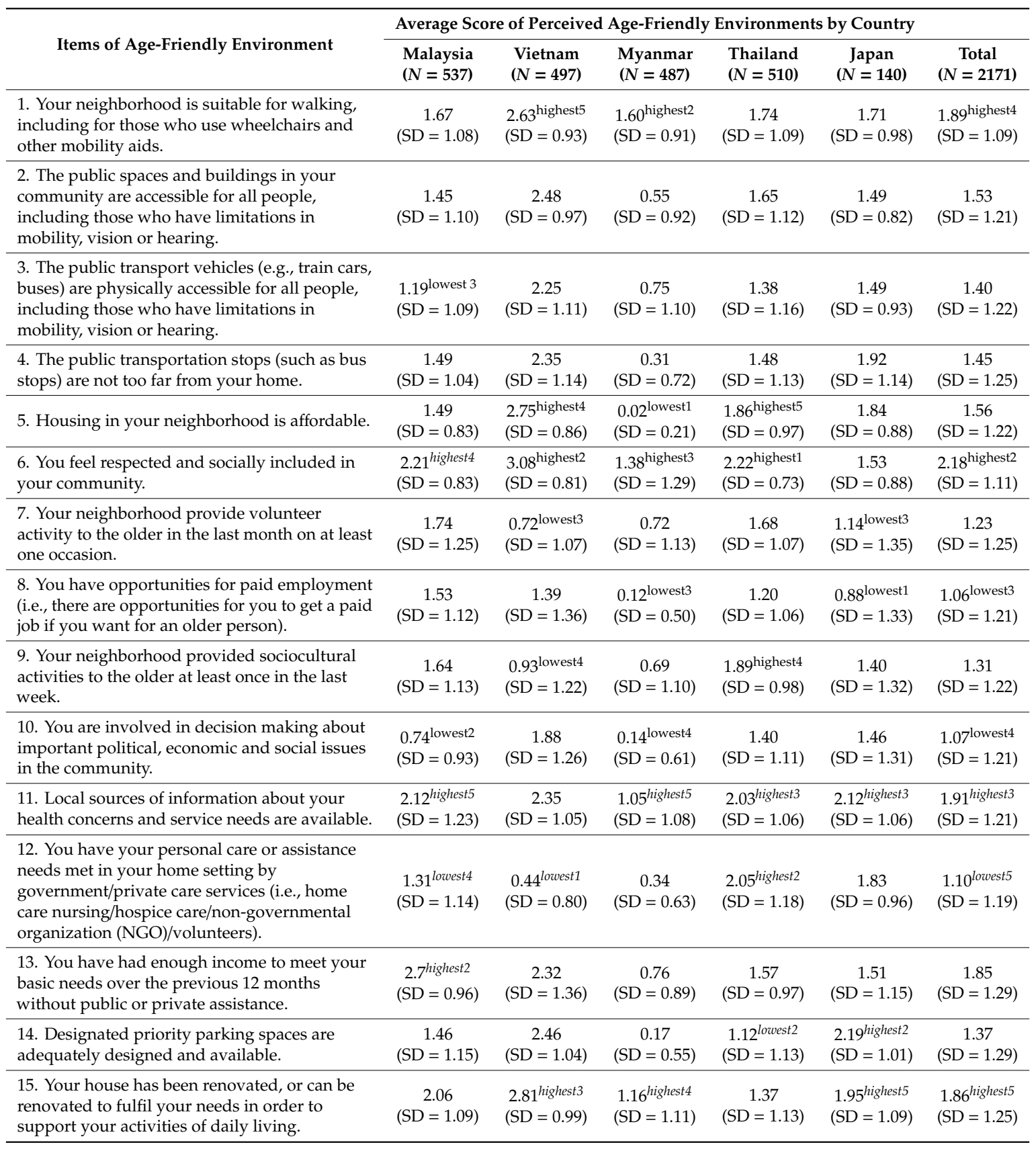


Table 2. Cont.

\begin{tabular}{|c|c|c|c|c|c|c|}
\hline \multirow{2}{*}{ Items of Age-Friendly Environment } & \multicolumn{6}{|c|}{ Average Score of Perceived Age-Friendly Environments by Country } \\
\hline & $\begin{array}{l}\text { Malaysia } \\
(N=537)\end{array}$ & $\begin{array}{l}\text { Vietnam } \\
(N=497)\end{array}$ & $\begin{array}{c}\text { Myanmar } \\
(N=487)\end{array}$ & $\begin{array}{l}\text { Thailand } \\
(N=510)\end{array}$ & $\begin{array}{c}\text { Japan } \\
(N=140)\end{array}$ & $\begin{array}{c}\text { Total } \\
(N=2171)\end{array}$ \\
\hline $\begin{array}{l}\text { 16. Your neighborhood provided group physical } \\
\text { activities in your leisure time. }\end{array}$ & $\begin{array}{c}1.64 \\
(S D=1.10)\end{array}$ & $\begin{array}{c}1.52 \\
(S D=1.44)\end{array}$ & $\begin{array}{c}0.25 \\
(S D=0.70)\end{array}$ & $\begin{array}{c}1.37 \\
(S D=1.10)\end{array}$ & $\begin{array}{c}1.69 \\
(S D=1.30)\end{array}$ & $\begin{array}{c}1.24 \\
(S D=1.25)\end{array}$ \\
\hline $\begin{array}{l}\text { 17. Your neighborhood provided the older the } \\
\text { ability to enroll in any form of education or } \\
\text { training, either formal or non-formal, in any } \\
\text { subject in the past year. }\end{array}$ & $\begin{array}{l}1.36^{\text {lowest } 5} \\
(S D=1.20)\end{array}$ & $\begin{array}{c}1.46 \\
(S D=1.47)\end{array}$ & $\begin{array}{c}0.16^{\text {lowest } 5} \\
(S D=0.66)\end{array}$ & $\begin{array}{l}1.16^{\text {lowest } 3} \\
(S D=1.07)\end{array}$ & $\begin{array}{l}0.88^{\text {lowest } 1} \\
(S D=1.17)\end{array}$ & $\begin{array}{l}1.04^{\text {lowest } 2} \\
(S D=1.24)\end{array}$ \\
\hline 18. You have access to internet at home. & $\begin{array}{l}3.19^{\text {highest } 1} \\
(S D=0.97)\end{array}$ & $\begin{array}{l}1.30^{\text {lowest } 5} \\
(S D=1.36)\end{array}$ & $\begin{array}{c}0.65 \\
(S D=1.12)\end{array}$ & $\begin{array}{c}0.86^{\text {lowest1 }} \\
(S D=1.09)\end{array}$ & $\begin{array}{l}1.96^{\text {highest } 4} \\
(S D=1.61)\end{array}$ & $\begin{array}{c}1.56 \\
(S D=1.54)\end{array}$ \\
\hline 19. You feel safe in your neighborhood. & $\begin{array}{l}2.51^{\text {highest3 }} \\
(S D=0.79)\end{array}$ & $\begin{array}{l}3.10^{\text {highest } 1} \\
(S D=0.85)\end{array}$ & $\begin{array}{l}2.96^{\text {highest1 }} \\
(S D=1.10)\end{array}$ & $\begin{array}{l}2.03^{\text {highest } 3} \\
(S D=1.04)\end{array}$ & $\begin{array}{l}2.21^{\text {highest } 1} \\
(S D=0.85)\end{array}$ & $\begin{array}{l}2.61^{\text {highest1 }} \\
(S D=1.03)\end{array}$ \\
\hline $\begin{array}{l}\text { 20. Your neighborhood provided the older } \\
\text { participating in an emergency-response training } \\
\text { session or drill in the past year which addressed } \\
\text { the needs of older residents. }\end{array}$ & $\begin{array}{c}0.40^{\text {lowest } 1} \\
(S D=0.89)\end{array}$ & $\begin{array}{c}0.50^{\text {lowest } 2} \\
(S D=0.86)\end{array}$ & $\begin{array}{c}0.06^{\text {lowest } 2} \\
(S D=0.34)\end{array}$ & $\begin{array}{c}1.18 \\
(S D=1.14)\end{array}$ & $\begin{array}{c}1.05^{\text {lowest } 2} \\
(S D=1.18)\end{array}$ & $\begin{array}{c}0.58^{\text {lowest } 1} \\
(S D=0.97)\end{array}$ \\
\hline \multicolumn{7}{|c|}{$\begin{array}{l}x^{\text {lowest } 1} x^{\text {lowest } 2} x^{\text {lowest } 3} x^{\text {lowest } 4} x^{\text {lowest } 5}=\text { item that have lowest score of perception as lowest } 1=\text { first lowest, lowest } \\
2=\text { second lowest, lowest } 3=\text { third lowest, lowest } 4=\text { fourth lowest, and lowest } 5=\text { fifth lowest for each country. } \\
X^{\text {highest } 1} x^{\text {highest } 2} X^{\text {highest } 3} x^{\text {highest } 4} X^{\text {highest5 }}=\text { item that have highest score of perception as highest } 1=\text { first highest, } \\
\text { highest } 2=\text { second highest, highest } 3=\text { third highest, highest } 4=\text { fourth highest, and highest } 5=\text { fifth highest for } \\
\text { each country. }\end{array}$} \\
\hline
\end{tabular}

\subsection{The Level of Perceived Age-Friendly Environments by Country}

In order to examine the differences in the proportion of perceived age-friendly environments by country, we recoded the perception into 3 levels as bad (not at all/a little), fair (moderately), and good (mostly/extremely). A Pearson chi-squared test was applied to examine the difference in the level of perceived age-friendly environments by country. The results from chi-squared test in Table 3, indicated the significant differences at $p<0.05$ in the proportion of all perceived age-friendly environments by country. Among the 20 items of age-friendly environments, the five highest percentage of inadequate age-friendly environments are (1) participating in an emergency response training session or drill in the past year which addressed the needs of older residents; (2) enrolling in any form of education or training, either formal or non-formal; (3) having opportunities for paid employment; (4) involving in decision making about important political, economic and social issues in the community; and (5) having the personal care or assistance needs met in home setting by government/private care services. Namely, most ASEAN older population (more than $80 \%$ ) perceived their emergency-response training session or drill as bad, especially more than $90 \%$ of the Vietnamese and Myanmarese older populations. Regarding education or training, almost $70 \%$ of the older adults perceived badly, especially most Myanmarese older adults (95.9\%). Similar to education or training, paid employment is also a big problem for the older population (almost $70 \%$ ) with inadequate opportunity to get employment, especially Myanmarese older adults (96.9\%). Regarding decision making about important political, economic and social issues in the community, $65 \%$ of the older population perceived it badly, especially $97.1 \%$ of Myanmarese and $77.1 \%$ of Malaysian older adults are not satisfied with it. For personal care or assistance needs met in their home setting, almost $65 \%$ of the older population perceived this to be inadequate, especially $96.7 \%$ of Myanmarese and $93.2 \%$ of Vietnamese older adults are not satisfied; however the result showed that only $29 \%$ of Thai older adults are dissatisfied. 
Table 3. The levels of perceived age-friendly environments by country (applied Pearson chi-squared test analysis).

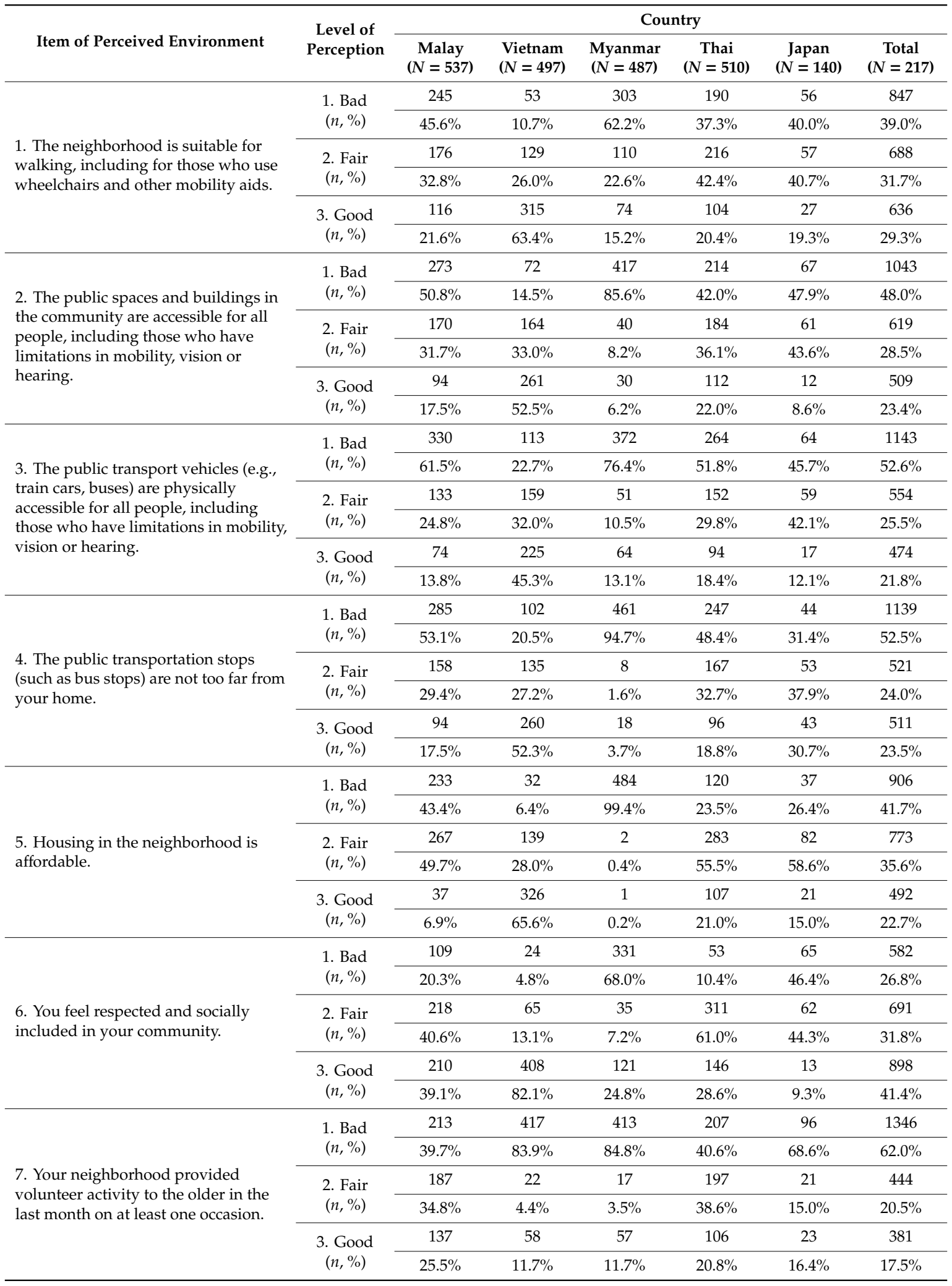


Table 3. Cont.

\begin{tabular}{|c|c|c|c|c|c|c|c|}
\hline \multirow[b]{2}{*}{ Item of Perceived Environment } & \multirow{2}{*}{$\begin{array}{c}\text { Level of } \\
\text { Perception }\end{array}$} & \multicolumn{6}{|c|}{ Country } \\
\hline & & $\begin{array}{c}\text { Malay } \\
(N=537)\end{array}$ & $\begin{array}{l}\text { Vietnam } \\
(N=497)\end{array}$ & $\begin{array}{l}\text { Myanmar } \\
(N=487)\end{array}$ & $\begin{array}{c}\text { Thai } \\
(N=510)\end{array}$ & $\begin{array}{c}\text { Japan } \\
(N=140)\end{array}$ & $\begin{array}{c}\text { Total } \\
(N=217)\end{array}$ \\
\hline \multirow{4}{*}{$\begin{array}{l}\text { 8. You have opportunities for paid } \\
\text { employment (i.e., there are } \\
\text { opportunities for you to get a paid job } \\
\text { if you want for an older person). }\end{array}$} & $\begin{array}{c}\text { 1. Bad } \\
(n, \%)\end{array}$ & $51.0 \%$ & $60.8 \%$ & $96.9 \%$ & $60.4 \%$ & $74.3 \%$ & $67.3 \%$ \\
\hline & $\begin{array}{l}\text { 2. Fair } \\
(n, \%)\end{array}$ & 134 & 59 & 8 & 141 & 14 & 356 \\
\hline & \multirow{2}{*}{$\begin{array}{l}\text { 3. Good } \\
(n, \%)\end{array}$} & 129 & 136 & 7 & 61 & 22 & 355 \\
\hline & & $24.0 \%$ & $27.4 \%$ & $1.4 \%$ & $12.0 \%$ & $15.7 \%$ & $16.4 \%$ \\
\hline \multirow{3}{*}{$\begin{array}{l}\text { 9. Your neighborhood provided } \\
\text { sociocultural activities to the older at } \\
\text { least once in the last week. }\end{array}$} & \multirow{2}{*}{$\begin{array}{l}\text { 1. Bad } \\
(n, \%)\end{array}$} & 240 & 382 & 413 & 143 & 75 & 1253 \\
\hline & & $44.7 \%$ & $76.9 \%$ & $84.8 \%$ & $28.0 \%$ & $53.6 \%$ & $57.7 \%$ \\
\hline & $\begin{array}{l}\text { 3. Good } \\
(n, \%)\end{array}$ & $21.6 \%$ & $17.1 \%$ & $10.1 \%$ & $22.7 \%$ & $20.0 \%$ & $18.1 \%$ \\
\hline \multirow{6}{*}{$\begin{array}{l}\text { 10. You are involved in decision } \\
\text { making about important political, } \\
\text { economic and social issues in the } \\
\text { community. }\end{array}$} & \multirow{2}{*}{$\begin{array}{l}\text { 1. Bad } \\
(n, \%)\end{array}$} & 414 & 193 & 473 & 259 & 73 & 1412 \\
\hline & & $77.1 \%$ & $38.8 \%$ & $97.1 \%$ & $50.8 \%$ & $52.1 \%$ & $65.0 \%$ \\
\hline & \multirow{2}{*}{$\begin{array}{l}\text { 2. Fair } \\
(n, \%)\end{array}$} & 96 & 117 & 1 & 176 & 40 & 430 \\
\hline & & $17.9 \%$ & $23.5 \%$ & $0.2 \%$ & $34.5 \%$ & $28.6 \%$ & $19.8 \%$ \\
\hline & \multirow{2}{*}{$\begin{array}{l}\text { 3. Good } \\
(n, \%)\end{array}$} & 27 & 187 & 13 & 75 & 27 & 329 \\
\hline & & $5.0 \%$ & $37.6 \%$ & $2.7 \%$ & $14.7 \%$ & $19.3 \%$ & $15.2 \%$ \\
\hline $\begin{array}{l}\text { 11. Local sources of information about } \\
\text { your health concerns and service } \\
\text { needs are available. }\end{array}$ & $\begin{array}{l}\text { 1. Bad } \\
(n, \%)\end{array}$ & 158 & 95 & 360 & 143 & 40 & 796 \\
\hline \multirow{6}{*}{$\begin{array}{l}\text { 12. You have your personal care or } \\
\text { assistance needs met in your home } \\
\text { setting by government/private care } \\
\text { services (i.e., home care } \\
\text { nursing/hospice } \\
\text { care/non-governmental organization } \\
\text { (NGO)/volunteers). }\end{array}$} & \multirow{2}{*}{$\begin{array}{c}\text { 1. Bad } \\
(n, \%)\end{array}$} & 261 & 463 & 471 & 148 & 45 & 1388 \\
\hline & & $48.6 \%$ & $93.2 \%$ & $96.7 \%$ & $29.0 \%$ & $32.1 \%$ & $63.9 \%$ \\
\hline & \multirow{2}{*}{$\begin{array}{c}\text { 2. Fair } \\
(n, \%)\end{array}$} & 208 & 15 & 9 & 186 & 68 & 486 \\
\hline & & $38.7 \%$ & $3.0 \%$ & $1.8 \%$ & $36.5 \%$ & $48.6 \%$ & $22.4 \%$ \\
\hline & \multirow{2}{*}{$\begin{array}{l}\text { 3. Good } \\
(n, \%)\end{array}$} & 68 & 19 & 7 & 176 & 27 & 297 \\
\hline & & $12.7 \%$ & $3.8 \%$ & $1.4 \%$ & $34.5 \%$ & $19.3 \%$ & $13.7 \%$ \\
\hline & 1. Bad & 49 & 141 & 402 & 241 & 67 & 900 \\
\hline & $(n, \%)$ & $9.1 \%$ & $28.4 \%$ & $82.5 \%$ & $47.3 \%$ & $47.9 \%$ & $41.5 \%$ \\
\hline meet your basic needs over the & 2. Fair & 145 & 97 & 63 & 204 & 50 & 559 \\
\hline & $(n, \%)$ & $27.0 \%$ & $19.5 \%$ & $12.9 \%$ & $40.0 \%$ & $35.7 \%$ & $25.7 \%$ \\
\hline & 3. Good & 343 & 259 & 22 & 65 & 23 & 712 \\
\hline & $(n, \%)$ & $63.9 \%$ & $52.1 \%$ & $4.5 \%$ & $12.7 \%$ & $16.4 \%$ & $32.8 \%$ \\
\hline & 1. Bad & 253 & 78 & 469 & 324 & 30 & 1154 \\
\hline & $(n, \%)$ & $47.1 \%$ & $15.7 \%$ & $96.3 \%$ & $63.5 \%$ & $21.4 \%$ & $53.2 \%$ \\
\hline 14. Designated priority parking spaces & 2. Fair & 190 & 141 & 10 & 131 & 61 & 533 \\
\hline are adequately designed and available. & $(n, \%)$ & $35.4 \%$ & $28.4 \%$ & $2.1 \%$ & $25.7 \%$ & $43.6 \%$ & $24.6 \%$ \\
\hline
\end{tabular}


Table 3. Cont.

\begin{tabular}{|c|c|c|c|c|c|c|c|}
\hline \multirow[b]{2}{*}{ Item of Perceived Environment } & \multirow{2}{*}{$\begin{array}{l}\text { Level of } \\
\text { Perception }\end{array}$} & \multicolumn{6}{|c|}{ Country } \\
\hline & & $\begin{array}{c}\text { Malay } \\
(N=537)\end{array}$ & $\begin{array}{l}\text { Vietnam } \\
(N=497)\end{array}$ & $\begin{array}{l}\text { Myanmar } \\
(N=487)\end{array}$ & $\begin{array}{c}\text { Thai } \\
(N=510)\end{array}$ & $\begin{array}{c}\text { Japan } \\
(N=140)\end{array}$ & $\begin{array}{c}\text { Total } \\
(N=217)\end{array}$ \\
\hline \multirow{6}{*}{$\begin{array}{l}\text { 15. Your house has been renovated or } \\
\text { can be renovated to fulfil your needs } \\
\text { in order to support your activities of } \\
\text { daily living. }\end{array}$} & \multirow{2}{*}{$\begin{array}{l}\text { 1. Bad } \\
(n, \%)\end{array}$} & 167 & 49 & 314 & 273 & 45 & 848 \\
\hline & & $31.1 \%$ & $9.9 \%$ & $64.5 \%$ & $53.5 \%$ & $32.1 \%$ & $39.1 \%$ \\
\hline & \multirow{2}{*}{$\begin{array}{l}\text { 2. Fair } \\
(n, \%)\end{array}$} & 202 & 107 & 110 & 156 & 56 & 631 \\
\hline & & $37.6 \%$ & $21.5 \%$ & $22.6 \%$ & $30.6 \%$ & $40.0 \%$ & $29.1 \%$ \\
\hline & \multirow{2}{*}{$\begin{array}{l}\text { 3. Good } \\
(n, \%)\end{array}$} & 168 & 341 & 63 & 81 & 39 & 692 \\
\hline & & $31.3 \%$ & $68.6 \%$ & $12.9 \%$ & $15.9 \%$ & $27.9 \%$ & $31.9 \%$ \\
\hline \multirow{6}{*}{$\begin{array}{l}\text { 16. Your neighborhood provide group } \\
\text { physical activities in your leisure time. }\end{array}$} & \multirow{2}{*}{$\begin{array}{l}\text { 1. Bad } \\
(n, \%)\end{array}$} & 230 & 300 & 463 & 288 & 61 & 1342 \\
\hline & & $42.8 \%$ & $60.4 \%$ & $95.1 \%$ & $56.5 \%$ & $43.6 \%$ & $61.8 \%$ \\
\hline & \multirow{2}{*}{$\begin{array}{l}\text { 2. Fair } \\
(n, \%)\end{array}$} & 213 & 35 & 11 & 143 & 43 & 445 \\
\hline & & $39.7 \%$ & $7.0 \%$ & $2.3 \%$ & $28.0 \%$ & $30.7 \%$ & $20.5 \%$ \\
\hline & \multirow{2}{*}{$\begin{array}{l}\text { 3. Good } \\
(n, \%)\end{array}$} & 94 & 162 & 13 & 79 & 36 & 384 \\
\hline & & $17.5 \%$ & $32.6 \%$ & $2.7 \%$ & $15.5 \%$ & $25.7 \%$ & $17.7 \%$ \\
\hline \multirow{6}{*}{$\begin{array}{l}\text { 17. Your neighborhood provided the } \\
\text { older the ability to enroll in any form } \\
\text { of education or training, either formal } \\
\text { or non-formal, in any subject in the } \\
\text { past year. }\end{array}$} & \multirow{2}{*}{$\begin{array}{l}\text { 1. Bad } \\
(n, \%)\end{array}$} & 267 & 312 & 467 & 318 & 97 & 1461 \\
\hline & & $49.7 \%$ & $62.8 \%$ & $95.9 \%$ & $62.4 \%$ & $69.3 \%$ & $67.3 \%$ \\
\hline & \multirow{2}{*}{$\begin{array}{l}\text { 2. Fair } \\
(n, \%)\end{array}$} & 191 & 30 & 6 & 143 & 28 & 398 \\
\hline & & $35.6 \%$ & $6.0 \%$ & $1.2 \%$ & $28.0 \%$ & $20.0 \%$ & $18.3 \%$ \\
\hline & \multirow{2}{*}{$\begin{array}{l}\text { 3. Good } \\
(n, \%)\end{array}$} & 79 & 155 & 14 & 49 & 15 & 312 \\
\hline & & $14.7 \%$ & $31.2 \%$ & $2.9 \%$ & $9.6 \%$ & $10.7 \%$ & $14.4 \%$ \\
\hline \multirow{6}{*}{$\begin{array}{l}\text { 18. You have access to internet at } \\
\text { home. }\end{array}$} & \multirow{2}{*}{$\begin{array}{l}\text { 1. Bad } \\
(n, \%)\end{array}$} & 18 & 320 & 374 & 368 & 58 & 1138 \\
\hline & & $3.4 \%$ & $64.4 \%$ & $76.8 \%$ & $72.2 \%$ & $41.4 \%$ & $52.4 \%$ \\
\hline & \multirow{2}{*}{$\begin{array}{l}\text { 2. Fair } \\
(n, \%)\end{array}$} & 111 & 57 & 55 & 96 & 25 & 344 \\
\hline & & $20.7 \%$ & $11.5 \%$ & $11.3 \%$ & $18.8 \%$ & $17.9 \%$ & $15.8 \%$ \\
\hline & \multirow{2}{*}{$\begin{array}{l}\text { 3. Good } \\
(n, \%)\end{array}$} & 408 & 120 & 58 & 46 & 57 & 689 \\
\hline & & $76.0 \%$ & $24.1 \%$ & $11.9 \%$ & $9.0 \%$ & $40.7 \%$ & $31.7 \%$ \\
\hline \multirow{6}{*}{ 19. You feel safe in your neighborhood. } & \multirow{2}{*}{$\begin{array}{l}\text { 1. Bad } \\
(n, \%)\end{array}$} & 26 & 25 & 54 & 138 & 21 & 264 \\
\hline & & $4.8 \%$ & $5.0 \%$ & $11.1 \%$ & $27.1 \%$ & $15.0 \%$ & $12.2 \%$ \\
\hline & \multirow{2}{*}{$\begin{array}{l}\text { 2. Fair } \\
(n, \%)\end{array}$} & 262 & 57 & 85 & 203 & 67 & 674 \\
\hline & & $48.8 \%$ & $11.5 \%$ & $17.5 \%$ & $39.8 \%$ & $47.9 \%$ & $31.0 \%$ \\
\hline & \multirow{2}{*}{$\begin{array}{l}\text { 3. Good } \\
(n, \%)\end{array}$} & 249 & 415 & 348 & 169 & 52 & 1233 \\
\hline & & $46.4 \%$ & $83.5 \%$ & $71.5 \%$ & $33.1 \%$ & $37.1 \%$ & $56.8 \%$ \\
\hline \multirow{6}{*}{$\begin{array}{l}\text { 20. Your neighborhood provided the } \\
\text { older participating in an emergency } \\
\text { response training session or drill in the } \\
\text { past year which addressed the needs } \\
\text { of older residents. }\end{array}$} & \multirow{2}{*}{$\begin{array}{c}\text { 1. Bad } \\
(n, \%)\end{array}$} & 470 & 459 & 481 & 316 & 89 & 1815 \\
\hline & & $87.5 \%$ & $92.4 \%$ & $98.8 \%$ & $62.0 \%$ & $63.6 \%$ & $83.6 \%$ \\
\hline & \multirow{2}{*}{$\begin{array}{c}\text { 2. Fair } \\
(n, \%)\end{array}$} & 48 & 7 & 4 & 133 & 34 & 226 \\
\hline & & $8.9 \%$ & $1.4 \%$ & $0.8 \%$ & $26.1 \%$ & $24.3 \%$ & $10.4 \%$ \\
\hline & 3. Good & 19 & 31 & 2 & 61 & 17 & 130 \\
\hline & $(n, \%)$ & $3.5 \%$ & $6.2 \%$ & $0.4 \%$ & $12.0 \%$ & $12.1 \%$ & $6.0 \%$ \\
\hline
\end{tabular}

Note: The results from Pearson chi-squared test show the significant association between country of participants and the level of the perceived age-friendly environment for all 20 items at $p<0.05$.

\subsection{High-Risk Group of Having Inadequate Age-Friendly Environments}

We identify a high-risk group of having inadequate age-friendly environments by analysis of ordinal logistic regression with $p<0.05$. The interested predictors include age level, gender, educational level, and participant's country. From Table 4, regarding Model 1*, the high-risk group of perceived low level of participating in an emergency response training session or drill which addressed the needs of older residents is the older population with low educational level. Namely, the results indicated that older adults with more than high school are significantly more likely to rate for a higher scale of 
perceived emergency-response training sessions or drills compared to the older adults with at least primary school, controlling for other socioeconomic statue (SES) and country of participants.

Table 4. Predictors of perceived "bad" age-friendly environments, analyzed by ordinal logistic regression with five perceived age-friendly environments as a three ordinal outcome scale (bad, fair, and good) and four predictors (educational level, gender, age level, and country of participants).

\begin{tabular}{|c|c|c|c|c|c|}
\hline \multirow{3}{*}{ Predictors } & \multicolumn{5}{|c|}{ Perceived Age-Friendly Environments } \\
\hline & Model 1 & Model 2 & Model 3 & Model 4 & Model 5 \\
\hline & $\begin{array}{c}\text { Odds Ratio } \\
\text { (95\% C.I.) }\end{array}$ & $\begin{array}{c}\text { Odds Ratio } \\
\text { (95\% C.I.) }\end{array}$ & $\begin{array}{c}\text { Odds Ratio } \\
\text { (95\% C.I.) }\end{array}$ & $\begin{array}{l}\text { Odds Ratio } \\
\text { (95\% C.I.) }\end{array}$ & $\begin{array}{l}\text { Odds Ratio } \\
\text { (95\% C.I.) }\end{array}$ \\
\hline \multicolumn{6}{|l|}{ 1. Education } \\
\hline $\begin{array}{c}\text { At least } \\
\text { Primary school }\end{array}$ & $\begin{array}{c}0.60 * \\
(0.41-0.88)\end{array}$ & $\begin{array}{c}0.48 * \\
(0.35-0.65)\end{array}$ & $\begin{array}{c}0.62 * \\
(0.46-0.83)\end{array}$ & $\begin{array}{c}0.37^{*} \\
(0.27-0.50)\end{array}$ & $\begin{array}{c}0.84 \\
(0.60-1.17)\end{array}$ \\
\hline High school & $\begin{array}{c}0.87 \\
(0.60-1.25)\end{array}$ & $\begin{array}{c}1.08 \\
(0.84-1.40)\end{array}$ & $\begin{array}{c}0.68 * \\
(0.52-0.90)\end{array}$ & $\begin{array}{c}0.70 * \\
(0.53-0.93)\end{array}$ & $\begin{array}{c}1.06 \\
(0.79-1.41)\end{array}$ \\
\hline $\begin{array}{l}\text { More than high } \\
\text { school (Reference) }\end{array}$ & 1 & 1 & 1 & 1 & 1 \\
\hline \multicolumn{6}{|l|}{ 2. Country } \\
\hline Malaysia & $\begin{array}{c}0.24 \text { * } \\
(0.15-0.38)\end{array}$ & $\begin{array}{c}1.53 \text { * } \\
(1.00-2.31)\end{array}$ & $\begin{array}{c}1.27 \\
(0.81-1.98)\end{array}$ & $\begin{array}{c}0.33 * \\
(0.22-0.49)\end{array}$ & $\begin{array}{c}0.56 \text { * } \\
(0.38-0.81)\end{array}$ \\
\hline Vietnam & $\begin{array}{c}0.18 \text { * } \\
(0.10-0.31)\end{array}$ & $\begin{array}{c}1.88 * \\
(1.20-2.93)\end{array}$ & $\begin{array}{c}1.92 * \\
(1.20-3.08)\end{array}$ & $\begin{array}{c}3.45 * \\
(2.26-5.25)\end{array}$ & $\begin{array}{c}0.04 * \\
(0.03-0.70)\end{array}$ \\
\hline Myanmar & $\begin{array}{c}0.03 * \\
(0.01-0.08)\end{array}$ & $\begin{array}{c}0.15 * \\
(0.08-0.28)\end{array}$ & $\begin{array}{c}0.08 * \\
(0.04-0.16)\end{array}$ & $\begin{array}{c}0.08 * \\
(0.04-0.16)\end{array}$ & $\begin{array}{c}0.02 * \\
(0.01-0.00)\end{array}$ \\
\hline Thailand & $\begin{array}{c}1.35 \\
(0.84-2.17)\end{array}$ & $\begin{array}{c}1.61^{*} \\
(1.03-2.53)\end{array}$ & $\begin{array}{c}1.55 \\
(0.96-2.49)\end{array}$ & $\begin{array}{c}1.91 * \\
(1.25-2.91)\end{array}$ & $\begin{array}{c}1.58 * \\
(1.04-2.40)\end{array}$ \\
\hline Japan (Reference) & 1 & 1 & 1 & 1 & 1 \\
\hline \multicolumn{6}{|l|}{ 3. Gender } \\
\hline Male & $\begin{array}{c}0.94 \\
(0.72-1.21)\end{array}$ & $\begin{array}{c}0.89 \\
(0.72-1.08)\end{array}$ & $\begin{array}{c}1.16 \\
(0.95-1.41)\end{array}$ & $\begin{array}{c}1.34 * \\
(1.10-1.63)\end{array}$ & $\begin{array}{c}0.78 * \\
(0.63-0.97)\end{array}$ \\
\hline Female (Reference) & 1 & 1 & 1 & 1 & 1 \\
\hline \multicolumn{6}{|l|}{ 4.Age level } \\
\hline 55-64 years & $\begin{array}{c}1.14 \\
(0.79-1.64)\end{array}$ & $\begin{array}{c}1.63 * \\
(1.20-2.21)\end{array}$ & $\begin{array}{c}4.97 * \\
(3.51-7.02)\end{array}$ & $\begin{array}{c}0.96 \\
(0.72-1.28) \\
\end{array}$ & $\begin{array}{c}0.92 \\
(0.67-1.26)\end{array}$ \\
\hline $65-74$ years & $\begin{array}{c}0.98 \\
(0.69-1.38)\end{array}$ & $\begin{array}{c}1.22 \\
(0.91-1.64)\end{array}$ & $\begin{array}{c}2.38 * \\
(1.70-3.34) \\
\end{array}$ & $\begin{array}{c}0.85 \\
(0.65-1.12) \\
\end{array}$ & $\begin{array}{c}0.86 \\
(0.63-1.16)\end{array}$ \\
\hline 75yrs up (Reference) & 1 & 1 & 1 & 1 & 1 \\
\hline
\end{tabular}

Regarding Model 2*, high-risk groups of perceived low level of education or training enrollment are the older population with low educational level and the oldest group. Apparently, the results indicated that older adults with the lowest educational level are significantly less likely to rate for a higher scale of perceived education or training enrollment compare to the older adults with the highest educational level, controlling for other SES and country of participants. Additionally, the older adults with 75 years and higher are significantly less likely to rate for a higher scale of perceived education 
or training enrollment compare to the older adults aged 55-64 years, controlling for other SES and country of participants.

Regarding Model $3^{*}$, high-risk groups of perceived low opportunities for paid employment are the older population with low educational level and the oldest group. Obviously, the results indicated that older adults with lower educational level are significantly less likely to rate for a higher scale of perceived opportunities for paid employment compared to the older adults with the highest educational level, controlling for other SES and country of participants. Additionally, the older adults aged 75 years and higher are significantly less likely to rate for a higher scale of perceived opportunities for paid employment compared to the older adults that are younger, controlling for other SES and country of participants.

Regarding Model $4^{*}$, high-risk groups of perceived low involvement in decision making about important issues in the community are the older adult population with low educational level and the female older adult population. Especially, the results indicated that older adults with lower educational level are significantly less likely to rate for a higher scale of perceived involvement in decision making about important political, economic and social issues in the community compared to the older adults with highest educational level, controlling for other SES and country of participants. Additionally, female older adults are significantly less likely to rate for a higher scale of perceived involvement in decision making about important political, economic and social issues in the community compared to male older adults, controlling for other SES and country of participants.

Regarding Model $5^{*}$, the high-risk group of perceived low level of having personal care or assistance needs was the male older adult population. Evidently, the results indicated that male older adults are significantly less likely to rate for a higher scale of perceiving having personal care or assistance needs met compared to the female older adults, controlling for other SES and country of participants.

\section{Discussion}

The study found significant differences in the proportion of perceived age-friendly environments by ASEAN Plus Three older populations. The analysis results from the chi-squared test and ordinal logistic regression identified that among the 20 items of age-friendly environments, the five highest unsatisfied age-friendly environments toward ASEAN Plus Three ageing population are: (1) the inadequacy of participating in an emergency response training session or drill in the past year which addressed the needs of older residents, especially in the older population with low educational level; (2) the inadequacy of enrolling in any form of education or training, either formal or non-formal, especially in the older population with low educational level and the oldest group; (3) the inadequacy of having opportunities for paid employment, especially in the older population with low educational level and the oldest group; (4) the inadequacy of involving in decision making about important political, economic and social issues in the community, especially in the older population with low educational level and female older adults; and (5) the inadequacy of having the personal care or assistance needs met in home setting by government/private care services, especially in male older adults.

There are some similarly satisfied age-friendly environments toward the ageing population in ASEAN Plus Three. Namely, the older population in Myanmar, Vietnam, and Japan similarly perceived a score of "they feel safe in their neighborhood" with the highest of all environments, whereas the Thai and Malaysian older population also perceived this item with the third highest of all. The most satisfied environments "feeling safe in their neighborhood" and "feeling respected in the community" was especially liked by Thai, Vietnamese, and Myanmarese older populations.

For the high-risk groups, the statistical analysis of ordinal logistic regression indicated that the older population with lower level of education is the high-risk group of "bad" perceived environment, especially for training issues, paid employment, and making decisions about important issues. Additionally, the study indicated that oldest aged adults was the high-risk group that significantly perceived a "bad" environment regarding education or training enrollment, and paid employment. 
Finally, we found gender disparity in the perception of decision making about important issues of males to be superior, and having personal care or assistance needs of females to be superior.

In agreement with previous researchers [26,27], our results indicated that ASEAN Plus Three older populations feel safe in their neighborhood. Past research also showed very high levels of trust and co-operation in the neighborhood among residents of Southeast Asia and higher levels of contribution towards the residents than those in North America and Europe [26]. A previous study [27] claimed that "increasing physical and cognitive constraints from being old may move them to gain more difficulties in completing some challenging tasks by themselves. Therefore, having more trust toward others contributes to the older adults more comfortableness to accept and rely on others' help". Additionally, it is noted that most people in ASEAN countries regularly live in the same place for generations and root deeply in the neighborhood. For these reasons, it is reasonable to identify that the older adults may have high levels of trust toward their neighbors [27]. In addition to perceived neighborhood safety, the results of our study also strongly support the respect of older adults of ASEAN generations. In the same line with our results, previous researchers indicated that respect for older adults is the most stressed expression of filial piety and it is deeply rooted in traditional Asian cultures [28-30]. The value of respect has retained its stability in the region for generations, however, evidence of changing respect expressions [30] including gestures and manners, tokens, customs and rituals, asking for advice, and obedience has occurred. Main factors associated with changing may include variations in family structure and function, education, income, and modernization [29]. Thus, it is a big challenge how ASEAN populations will retain deeply rooted values in a changing world.

Interestingly, this is the first study to indicate the inadequacy of emergency-response training toward older populations in ASEAN Plus Three, especially the older population with low education. In fact, aging brings many disadvantages to the older adults due to their physical, mental, and cognitive impairment-related aging process. In recent years [31] assistive technologies, such as the mobile and wearable sensors, assistive robots, smart homes, and smart fabrics for emergency response were introduced to maintain the independence of older populations, as well as to monitor and improve their health conditions. Although emergency assistive technologies are useful for older adults, previous research indicated [32] that aged populations even in a modern country such as Japan, have a more negative attitude towards performing basic life support. Therefore, there are still many challenges to help the older adults gain more confidence and skill with the essential elements of emergency response, especially those with low educational level. Besides emergency training, our results indicated the inadequacy of enrolling in any form of education or training, either formal or non-formal, or lifelong learning, especially in the older adults with low education and the oldest group. There is evidence that lifelong learning could promote older adults' health and well-being [33,34]. Therefore, some researchers tried to investigate appropriate practical courses for older adults and found that languages and health-related topics were the most popular among the older adults, especially in China [35] and the USA [36]. Interestingly, our study also showed that Japanese older adults living in modern society perceive an inadequate quantity of education and training to be supplied. Living in a nation with high literacy and technically advances in science and technology may be the reason why Japanese older adults are being challenged to constantly acquire new knowledge and skills [37]. The evidence of this study indicates a challenge for educators to provide continuing education opportunities with various and appropriate practices towards the older adults in ASEAN Plus Three countries.

Regarding the perceived paid employment, it is evident that almost $70 \%$ of older adults are in need of paid employment support, especially the older populations with less education. Along the same lines as our results, research showed that older adults in less developed countries are more likely to face economic necessities, especially the uneducated workers [38]. Our results also found that even the older populations in Japan are in need of employment. Consistent with the results of our study, a previous study [38] indicated that Japanese older adults prefer to extend their work after retirement. The researcher explained that the reasons that Japanese older adults prefer to keep working are: (1) they want to keep their standard of living as it was in their late 50s; and (2) they 
are concerned about society's norms that value the older adults staying in the labor force as long as possible. Some other countries in ASEAN, such as Thailand and Vietnam, attempt to initiate a national plan to delay the retirement age for maintaining the older adults at work, thus leading to more active ageing and economic security. Our results indicate the need of work at retirement age for all regions and, therefore, it is a challenge to policy makers how to allocate appropriate work for the older populations with long-term experiences but minor difficulty in physical conditions.

Decision-making about important political, economic and social issues in the community is another inadequate environment item of the older populations, especially the older adults with low education and being female. Like our research, a previous study found disparity of social participation including collective, productive, and political participation by socioeconomic status [39]. The researcher addressed that "older men are more likely to be engaged in paid work outside the home, even after retirement, in political activities and clubs, whereas older women more often take care of children (or grandchildren) and do more volunteer work and caregiving outside the home". Another study also supported that [40] older adult males have an important role in making decisions on important issues such as economic or political subjects, whereas older adult women tend to provide non-economic contributions to families, such as women's health or social services volunteers in communities. In addition to gender, research [39] also stressed that "persons who possess more educational and occupational resources may participate in social participation longer than persons with fewer resources, even after their health declines".

Lastly, an unsatisfied age-friendly environment is about inadequacy of the personal care or assistance needs met in a home setting, especially in Vietnam and Myanmar. Compared with the older adults in other countries, our results confirmed that older adults in Thailand have most satisfaction with the personal care or assistance needs at home. It is evident that all communities throughout the country of Thailand are equipped with strong community-based care for the older adult populations with more than 20 years countrywide 'elders' clubs' offered for older adult people [41]. Moreover, the country exists with the village health volunteers (VHVs) handling the older adults at home that have long been recognized by the World Health Organization as an international model for community-based public health. These reasons may explain why Thai older adult populations are more satisfied with personal care or assistance needs met in their home [42].

The results of this study can assist policy planners in building more appropriate age-friendly environments towards older adult populations in the ASEAN Plus Three. The priorities of environments for aging adult populations should be boosted towards active ageing as follows: (1) increasing an emergency-response training session or drill which addresses the needs of older residents, especially older adults with lower education; (2) giving any form of education or training, either formal or non-formal especially to older adults with lower education and the oldest group; (3) maintaining opportunities for paid employment for older adults in need; (4) supporting social participation and decision making about important political, economic and social issues in the community, especially for female and low-educated older adults; and (5) increasing the personal care or assistance needs met in a home setting by government/private care services (e.g., home care nursing/hospice care/non-governmental organization (NGO)/volunteers)", especially in male older adult populations.

There are some limitations to this study. First, the nature of the cross-sectional design of the study cannot confirm the causal relationships between age-friendly environments and the predictors. Second, data collection is diversified as the trained researchers in each country may have different skills, and thus, the study may have data collection bias. Third, the measurement of age-friendly environments in this study relied on perceived rather than objective measures of the environments. However, the present study has its strengths as it is the first study to survey age-friendly environments in ASEAN Plus Three, therefore, gaining knowledge and evidence for societies being cooperative in catering for ageing adult populations in these regions. 


\section{Conclusions}

The growing trend of worldwide ageing adult populations is the main challenge of creating age-friendly environments. The present study significantly indicates the perception of the older adult populations' concerns about age-friendly environments in the ASEAN Plus Three countries. In order to help communities to become age-friendly, priorities of environmental improvement need to be considered including: (1) increasing emergency-response training sessions or drills that addresses the needs of older adult residents: (2) giving any form of education or training, either formal or non-formal for older adults: (3) maintaining opportunities for paid employment for the older adults in need; (4) supporting social participation and decision making about important political, economic and social issues in the communities; and (5) increasing the personal care or assistance needs met in home settings by government/private care services.

Author Contributions: S.T. participated in the conception, design, data collection, analyzing data and writing the manuscript. D.B., M.M., T.H.N., A.H.M., M.Y. and M.N.A., supervised all data collection process, analyzed data and edited the manuscript for Thailand, Malaysia, Vietnam, Myanmar, and Japan, respectively. All authors have read and agreed to the published version of the manuscript.

Funding: This research project is supported by Thailand Science Research and Innovation (TSRI).

Acknowledgments: The authors thank all participants in this project including staff, fieldworkers, respondents and local authorities for their kind sharing and efforts.

Conflicts of Interest: The authors declare no conflict of interest.

\section{References}

1. United Nations. World Population Ageing. 2017. Available online: Https:/www.Un.Org/en/development/ desa/population/publications/pdf/ageing/wpa2017_highlights.Pdf (accessed on 10 May 2020).

2. United Nations. World Population Ageing. 2019. Available online: https:/www.Un.Org/en/development/ desa/population/publications/pdf/ageing/worldpopulationageing2019-highlights.Pdf (accessed on 11 May 2020).

3. WHO. Global Age-Friendly Cities: A Guide. 2016. Available online: https://www.Who.Int/ageing/ publications/global_age_friendly_cities_guide_english.Pdf (accessed on 21 June 2020).

4. Van Hoof, J.; Kazak, J.K.; Perek-Białas, J.M.; Peek, S. The challenges of urban ageing: Making cities age-friendly in Europe. Int. J. Environ. Res. Public Health 2018, 15, 2473. [CrossRef]

5. van Hoof, J.; Dikken, J.; Buttigieg, S.C.; van den Hoven, R.F.; Kroon, E.; Marston, H.R. Age-friendly cities in the Netherlands: An explorative study of facilitators and hindrances in the built environment and ageism in design. Indoor Built Environ. 2020, 29, 417-437. [CrossRef]

6. Marston, H.R.; van Hoof, J. “Who doesn't think about technology when designing urban environments for older people?" A case study approach to a proposed extension of the Who's age-friendly cities model. Int. J. Environ. Res. Public Health 2019, 16, 3525. [CrossRef] [PubMed]

7. Kurtyka-Marcak, I.; Hełdak, M.; Przybyła, K. The actual demand for the elimination of architectural barriers among senior citizens in poland. Int. J. Environ. Res. Public Health 2019, 16, 2601. [CrossRef] [PubMed]

8. Orpana, H.; Chawla, M.; Gallagher, E.; Escaravage, E. Developing indicators for evaluation of age-friendly communities in canada: Process and results. Health Promot. Chronic Dis. Prev. Can. Res. Policy Pract. 2016, 36, 214. [CrossRef]

9. Plouffe, L.A.; Kalache, A. Making communities age friendly: State and municipal initiatives in Canada and other countries. Gac. Sanit. 2011, 25, 131-137. [CrossRef] [PubMed]

10. Clark, K.; Glicksman, A. Age-friendly philadelphia: Bringing diverse networks together around aging issues. J. Hous. Elder. 2012, 26, 121-136. [CrossRef]

11. Clark, K. Genphilly: A strategy for improving the sustainability of aging in community initiatives. J. Aging Soc. Policy 2014, 26, 197-211. [CrossRef]

12. Ring, L.; Glicksman, A.; Kleban, M.; Norstrand, J. The future of age-friendly: Building a more inclusive model using principles of ecology and social capital. J. Hous. Elder. 2017, 31, 117-129. [CrossRef] 
13. Smith, R.J.; Lehning, A.J.; Dunkle, R.E. Conceptualizing age-friendly community characteristics in a sample of urban elders: An exploratory factor analysis. J. Gerontol. Soc. Work 2013, 56, 90-111. [CrossRef]

14. Oh, P.A. Age-friendly communities developing age-friendly communities: Evidence from multiple case studies. Innov. Aging 2019, 3, S183. [CrossRef]

15. Glicksman, A.; Clark, K.; Kleban, M.H.; Ring, L.; Hoffman, C. Building an integrated research/policy planning age-friendly agenda. J. Aging Soc. Policy 2014, 26, 131-146. [CrossRef] [PubMed]

16. Scharlach, A. Creating aging-friendly communities in the United States. Ageing Int. 2012, 37, $25-38$. [CrossRef]

17. Kendig, H.; Elias, A.-M.; Matwijiw, P.; Anstey, K. Developing age-friendly cities and communities in Australia. J. Aging Health 2014, 26, 1390-1414. [CrossRef]

18. Atkins, M. Boomers in boomtown: Age-friendly planning in Australia. Plan. Boomtown Beyond 2016, 4, 70-102.

19. Taylor, A.; Payer, H. Population ageing in northern Australia: Seniors' voices on ageing in place. J. Popul. Ageing 2017, 10, 181-196. [CrossRef]

20. Winterton, R. Organizational responsibility for age-friendly social participation: Views of Australian rural community stakeholders. J. Aging Soc. Policy 2016, 28, 261-276. [CrossRef]

21. ASEAN. Asean Plus Three Statement on Active Ageing. 2016. Available online: https://asean.Org/aseanplus-three-statement-on-active-ageing/ (accessed on 11 May 2020).

22. Chiangmai University. Final Report: The Study of Age-Friendly Environment for Asean+3 Countries, Proposed to the Department of Older Persons, the Ministry of Social Development and Human Security, Thailand; Chiangmai University: Chiangmai, Thailand, 2016.

23. Department of Older Persons, Thailand and College of Population Studies, Chulalongkorn University. Research Project on Care for Older Persons in Asean+3; BKK; Chulalongkorn University: Bangkok, Thailand, 2018.

24. WHO. Measuring the Age-Friendliness of Cities: A Guide to Using Core Indicators. 2015. Available online: https://www.Who.Int/ageing/publications/measuring-cities-age-friendliness/en/ (accessed on 11 May 2020).

25. Tiraphat, S.; Peltzer, K.; Thamma-Aphiphol, K.; Suthisukon, K. The role of age-friendly environments on quality of life among Thai elderly. Int. J. Environ. Res. Public Health 2017, 14, 282. [CrossRef]

26. Carpenter, J.P.; Daniere, A.G.; Takahashi, L.M. Social capital and trust in south-east Asian cities. Urban Stud. 2004, 41, 853-874. [CrossRef]

27. Li, T.; Fung, H.H. Age differences in trust: An investigation across 38 countries. J. Gerontol. Ser. B Psychol. Sci. Soc. Sci. 2013, 68, 347-355. [CrossRef]

28. Kim, B.J. Respect for the Elderly: Implications for Human Service Providers; University Press of America: Lanham, MD, USA, 2009.

29. Ingersoll-Dayton, B.; Saengtienchai, C. Respect for the elderly in Asia: Stability and change. Int. J. Aging Hum. Dev. 1999, 48, 113-130. [CrossRef] [PubMed]

30. Sung, K.-T. Elder respect: Exploration of ideals and forms in East Asia. J. Aging Stud. 2001, 15, 13-26. [CrossRef]

31. Rashidi, P.; Mihailidis, A. A survey on ambient-assisted living tools for elderly. IEEE J. Biomed. Health Inform. 2012, 17, 579-590. [CrossRef]

32. Enami, M.; Takei, Y.; Inaba, H.; Yachida, T.; Ohta, K.; Maeda, T.; Goto, Y. Differential effects of ageing and bls training experience on attitude towards basic life support. Resuscitation 2011, 82, 577-583. [CrossRef] [PubMed]

33. Williamson, A. 'You're never too old to learn!': Third-age perspectives on lifelong learning. Int. J. Lifelong Educ. 1997, 16, 173-184. [CrossRef]

34. Escuder-Mollon, P.; Esteller-Curto, R.; Ochoa, L.; Bardus, M. Impact on senior learners' quality of life through lifelong learning. Procedia-Soc. Behav. Sci. 2014, 131, 510-516. [CrossRef]

35. Leung, A.; Lui, Y.-H.; Chi, I. Later life learning experience among Chinese elderly in Hong Kong. Gerontol. Geriatr. Educ. 2006, 26, 1-15. [CrossRef] [PubMed]

36. Lamdin, L.S.; Fugate, M. Elderlearning: New Frontier in An Aging Society; Rowman \& Littlefield Publishers: Lanham, MD, USA, 1997.

37. Ogden, A.C. A brief overview of lifelong learning in Japan. Lang. Teach. 2010, 34, 5-13. 
38. Arifin, E.N.; Ananta, A. Employment of older persons: Diversity across nations and subnations in southeast Asia. In Older Persons in Southeast Asia. An Emerging Asset; Institute of Southeast Asian Studies: Singapore, 2009; pp. 167-217.

39. Bukov, A.; Maas, I.; Lampert, T. Social participation in very old age: Cross-sectional and longitudinal findings from base. J. Gerontol. Ser. B Psychol. Sci. Soc. Sci. 2002, 57, P510-P517. [CrossRef]

40. Teerawichitchainan, B.; Prachuabmoh, V.; Knodel, J. Productive aging in developing southeast Asia: Comparative analyses between myanmar, vietnam and thailand. Soc. Sci. Med. 2019, 229, 161-171. [CrossRef]

41. Ritchie, M.A. Social capacity, sustainable development, and older people: Lessons from community-based care in Southeast Asia. Dev. Pract. 2000, 10, 638-649. [CrossRef]

42. Kowitt, S.; Emmerling, D.; Fisher, E.; Tanasugarn, C. Community health workers as agents of health promotion: Analyzing Thailand's village health volunteer program. J. Community Health 2015, 40, 780-788. [CrossRef] [PubMed]

(C) 2020 by the authors. Licensee MDPI, Basel, Switzerland. This article is an open access article distributed under the terms and conditions of the Creative Commons Attribution (CC BY) license (http://creativecommons.org/licenses/by/4.0/). 